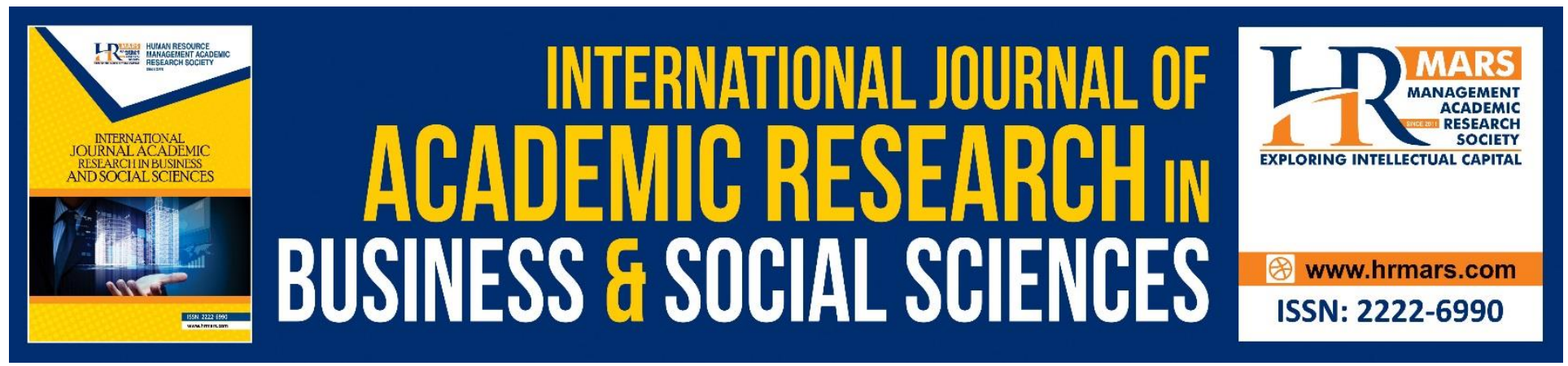

\title{
An Investigation into Hiking Motivation
}

Yeni Yuniawati, Oce Ridwanudinm, Dewi Pancawati

To Link this Article: http://dx.doi.org/10.6007/IJARBSS/v9-i3/5744

DOI: $\quad 10.6007 /$ IJARBSS/v9-i3/5744

Received: 06 Feb 2019, Revised: 27 Feb 2019, Accepted: 13 March 2019

Published Online: 28 March 2019

In-Text Citation: (Yuniawati, Ridwanudinm, \& Pancawati, 2019)

To Cite this Article: Yuniawati, Y., Ridwanudinm, O., \& Pancawati, D. (2019). An Investigation into Hiking Motivation. International Journal of Academic Research in Business and Social Sciences, 9(3), 782-788.

\section{Copyright: (C) 2019 The Author(s)}

Published by Human Resource Management Academic Research Society (www.hrmars.com)

This article is published under the Creative Commons Attribution (CC BY 4.0) license. Anyone may reproduce, distribute, translate and create derivative works of this article (for both commercial and non-commercial purposes), subject to full attribution to the original publication and authors. The full terms of this license may be seen

at: http://creativecommons.org/licences/by/4.0/legalcode

Vol. 9, No. 3, 2019, Pg. 782 - 788

http://hrmars.com/index.php/pages/detail/IJARBSS

JOURNAL HOMEPAGE

Full Terms \& Conditions of access and use can be found at http://hrmars.com/index.php/pages/detail/publication-ethics 


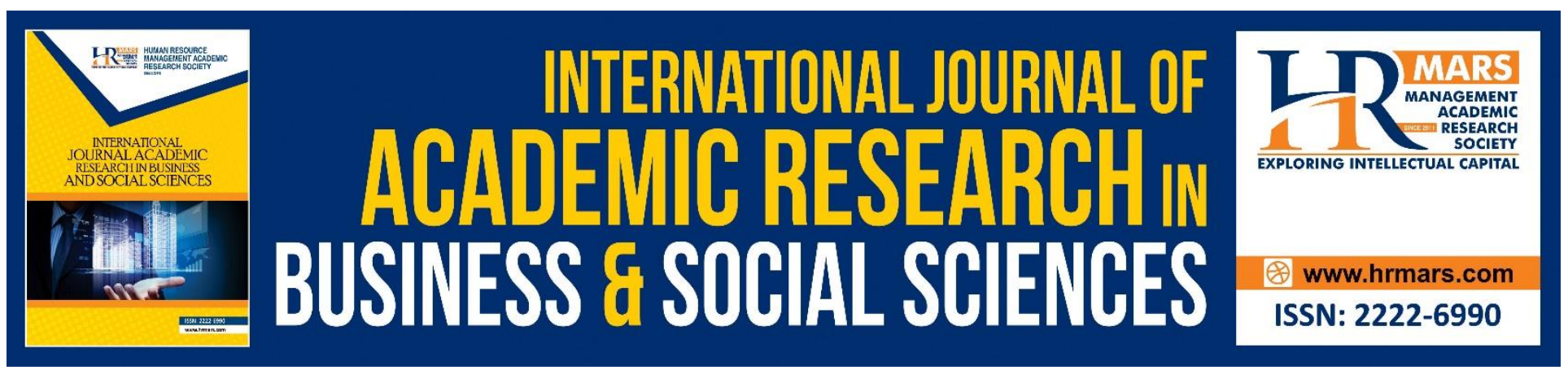

\title{
An Investigation into Hiking Motivation
}

\author{
Yeni Yuniawati, Oce Ridwanudinm, Dewi Pancawati \\ Universitas Pendidikan Indonesia, Indonesia
}

\begin{abstract}
Sport tourism is one of the types of tourism being developed in Indonesia. Although it is not as famous as nature tourism, it can be an alternative for those who enjoy physical activity and being outdoor at the same time. This study was aimed to investigate participants' motivation doing outdoor activity specifically hiking in Indonesia. Quantitative method was used in this study. Data was collected through distribution of questionnaire to 400 respondents who hiked in Ciremai Mountain and Papandayan Mountain in West Java and was analyzed using Confirmatory Factor Analysis (CFA) The descriptive result showed that based on respondents' response, learning and sociality obtained the highest score, while CFA test result indicated that learning and socializing was the most dominant indicator in forming outdoor activity motivation and the least dominant was relaxation.
\end{abstract}

Keywords: Outdoor Activity, Sport Tourism, Motivation, Mountain

\section{Introduction}

Sport tourism is a dynamically growing type of tourism and sport itself is becoming a powerful industry contributing greatly to economy as well as an important cultural element (Grabowska, 2016). Sport tourism is defined in many ways, some of them are Gibson, (1998), who defines sport tourism as tourist trips to participate in sport activities (active sports tourism), to watch sporting events (event sports tourism/ fan-tourism) or to visit sport attraction (nostalgia/sentimental sport tourism), while according to Standeven, Joy \& Knop, (1999). sport tourism is all forms of active and passive engagement in physical activity, both occasionally or regularly, which is undertaken for noncommercial or non-business purposes, and which requires travelling outside the place of permanent residence and work. Another definition from Gozalova, Shchikanov, Vernigor, \& Bagdasarian (2014) sports tourism includes travel away from one's primary residence to partake in a sports activity either for recreation or competition purpose, travel to observe sports at the grassroots or elite level, and travel to visit a sports attraction such as a sports hall of fame or water park. Sport tourism and outdoor activity/recreation are somehow intertwined since certain types of sport tourism are practiced outdoor (Grabowska, 2016). The two types of outdoor recreation are human power and mechanized. Human power outdoor recreation, where enthusiast is providing the power to participate in the activity, includes hiking, trail running, hunting, biking, kayaking and rafting, skiing and backpacking (Spector, 2015). Hiking is also often defined as one of adventure tourism, depending 
on whether it was conducted in relaxed or strenuous manner (Buckley, 2010). Hiking is one of the famous types of since it can be enjoyed by almost everyone due to its mostly low cost and is considered to be getting high interest (Shanks, 2018). It combines fun, exercise and self-mastery and is adapted to participant's physical skill (Cordelll et al., 1999). Nordbø \& Prebensen (2016) argue beside closely related with physical benefit, hiking is also contributed to mental benefit and Svarstad, (2017) points out that hiking provides opportunities for people to create a sense of continuity and belonging with their own lives and their close family with reference to landscape where they create long personal relationship though their hiking activity.

Manfredo, et al (1996) stated that motivations are key concepts in determining and understanding the reasons for leisure time activities of individuals and leisure time process (Manfredo, Driver, \& Tarrant, 1996). Studies were conducted to gain deeper understanding in what motivate tourists to participate is outdoor activities such as trekking, hiking, and walking. Grabowska, (2016) studied visitors to Tantra National Park Poland and discovered that their motivations were cathartic, activity, health, social, emotional, ambition and cognitive. Another study on motivation in outdoor/nature activity was conducted by Asan and Emeksiz (2016) which resulted in relaxation, learning and sociality, achievement, independence and personal development as motivations for participants in nature activity (Asan \& Emeksiz, 2016). A more specified study on hikers' motivation in South Korea was carried out by Kim, et al., (2015) who pointed out that their motivations were related to enjoying the natural environment and escaping from daily life, pursuing new type of travel, pursuing healthy life, and pursuing intimacy Chang, Hung, \& Wang, (2010) found out that motivations of doing physical activities were physical fitness, interpersonal interaction, weight control and release. Mehmetoglu \& Normann, (2013) investigated three different outdoor activities (whale safari, fishing, and hiking) in Norway and learned that novelty, prestige and physical activity were the main causes of motivation in participation.

Therefore, the main objective of this research is to find out about the participants' motivation to do hiking on two mountains in Indonesia.

\section{Methodology}

\section{Study Design}

We decided to conduct the study in two mountains in West Java that was Ciremai Mountain and Papandayan Mountain. Both were famous among hikers and had the most visitors especially during long holidays. We did observation by visiting the two mountains in July and did some interviews with the managers where we were introduced to hiking community in both places. We designed the questionnaire based on questionnaire from Asan \& Emeksiz, (2016) and made necessary adjustment. The survey was conducted from the second week of July towards the end of the month. The number of total population in both mountains was 383,970 in 2017 or about 32,000 per month in average, and the number of sample based on Slovin formula was 411 . Due to time and funding constraint, we distributed the questionnaires in two ways; direct and indirect. Direct questionnaire distribution was done to all hikers in both mountains that came on the weekends (Saturday and Sunday) as many as 200 sets, while indirect distribution was done online (with Google form) to hiking communities to which we distributed another 200 sets. We employed convenience sampling technique in the distribution. All of the 400 questionnaires were usable and provided good data. 
INTERNATIONAL JOURNAL OF ACADEMIC RESEARCH IN BUSINESS AND SOCIAL SCIENCES

Vol. 9, No. 3, March, 2019, E-ISSN: 222 2-6990 (C) 2019 HRMARS

\section{Construct and Measurement}

To measure outdoor activity motivation, we adapted four measurements from Asan and Emeksiz (Asan \& Emeksiz, 2016) which consisted of achievement, learning and socializing, independent and personal, and relaxation. Using Likert scale from 1 to 5 , respondents were requested to give their response on the statements given.

CFA was employed to measure the validity and reliability of construct in which the standard value to measure validity was 0.50 and the value to measure reliability was $>0.70$. P-value, RMSEA, CFI and GFI were used as measurements to test model fit, with standard value consecutively at $<0.05,<0.08$, $>0.90$ and $>0.90$.

\section{Results}

\section{Description of Samples}

Of 400 distributed questionnaire, $72 \%$ of them were male while the remaining $28 \%$ were female. Their age was ranging from 18 to 40 years old or above, with most were at 18 to 25 years old (69\%) and were high school graduates (54\%). Their purpose of hiking was mostly vacationing (90.5\%), it was not surprising since the questionnaires were distributed during weekend. Most of them spent one night $(75.5 \%)$ and only $4 \%$ spent more than three nights. $80 \%$ of them went hiking with three people or more, since they considered hiking was more fun to be done in group -- the more the merrier -and during the hike $86.5 \%$ of them spent between IDR 500,000 (\$35) to IDR 1,000,000 (\$70) including ticket, meals, and other costs.

\section{Descriptive Statistics}

Result of descriptive analysis showed that respondents gave highest score for learning and socializing (9077) as their motivation to do outdoor activity ie hiking, on the other hand they considered relaxation as the least factor that motivated them (5650). Overall score for each dimensions of outdoor activity motivation is presented in Table 3.2 below.

Table 3.2: Response to Outdoor Activity Motivation

\section{Testing Result}

Outdoor activities motivation construct was measured though four dimensions, they were achievement, learning and socializing, independent and personal and relaxation.
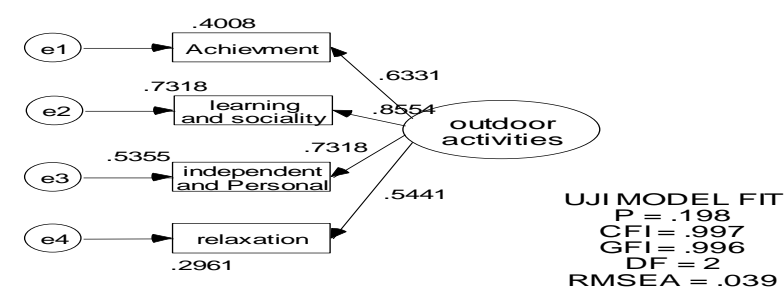

\begin{tabular}{llll}
\hline No & Dimensions & Score \\
\hline 1 & Achievement & 8454 \\
2 & $\begin{array}{l}\text { Learning } \\
\text { socializing } \\
\text { Independent } \\
\text { personal } \\
\text { development }\end{array}$ & and & 9077 \\
4 & Relaxation & 7023 \\
\hline
\end{tabular}

Figure 3.1: Parameter estimate of the hypothetical structural model 
Figure 3.1 above shows that the model suitability test results provided a P-value below 0.05 , which was 0.00 , and the RMSEA value produced was 0.039 or above the standardized value of $<0.08$. Furthermore, when viewed from the value of CFI and GFI, that was 0.997 and 0.996 respectively, both values were above the standardized value of $>0.90$. Thus, it could be concluded that the results of the model suitability test indicated that the proposed model was fit with the data. This meant that the model was able to provide population estimation that were not different from the sample data. The result of measurement estimation for both variables is presented in Table 3.2 below.

Table 3.2 Result of Parameter Estimation for Outdoor Activity Motivation Model

\begin{tabular}{|c|c|c|c|c|c|c|c|c|c|}
\hline \multirow{2}{*}{$\begin{array}{l}\text { Measurement } \\
\text { model }\end{array}$} & \multicolumn{2}{|l|}{ Estimate } & \multirow[t]{2}{*}{ S.E. } & \multirow[t]{2}{*}{ CR } & b & \multirow[t]{2}{*}{$\mathbf{R}^{2}$} & \multirow[t]{2}{*}{ Error } & \multirow[t]{2}{*}{$\mathbf{C R}_{\mathbf{i}}$} & \multirow[t]{2}{*}{$\mathrm{VE}_{\mathrm{i}}$} \\
\hline & $\begin{array}{l}\text { Reg } \\
\text { Weights }\end{array}$ & $\begin{array}{l}\text { Std Reg } \\
\text { Weights }\end{array}$ & & & & & & & \\
\hline \multicolumn{10}{|l|}{ OA } \\
\hline$A C \leftarrow O A$ & 1.000 &. .6331 & & & & .4008 & .5992 & & \\
\hline $\mathrm{LS} \leftarrow \mathrm{OA}$ & 1.255 & .8554 & .106 & 11.857 & $* * *$ & .7318 & .2682 & .78 & .49 \\
\hline $\mathrm{IP} \leftarrow \mathrm{OA}$ & .903 & .7318 & .079 & 11.496 & $* * *$ & .5355 & .4645 & & \\
\hline $\mathrm{RE} \leftarrow \mathrm{OA}$ & .510 & .5441 & .056 & 9.185 & $* * *$ & .2961 & .7039 & & \\
\hline
\end{tabular}

Based on Table 3.2, it can be seen that all dimensions had factor weight coefficient above the standardized value, which was 0.50 . It meant that all dimensions had adequate validity and reliability in measuring outdoor activities motivation variable.

When viewed based on the value of construct reliability, the measurement model provides a constructive reliability coefficient above the standardized value $(0.70)$, which is equal to 0.78 . This means that unidimesional outdoor activities are able to be measured by Achievement, Learning, Independent and Relaxation dimensions. Table 3.3 provides information that the dominant dimensions in the formation of outdoor activities, namely leaning with validity and reliability values of 0.8554 and 0.7318 . While the relaxation dimension has the lowest value of validity and reliability that is equal to 0.5441 and 0.2961 .

\section{Discussion}

This study revealed that learning and socializing was the dominant indicator in outdoor activity motivation. This result was supported by a study conducted by Kreiner and Kliot [4] in Israel National Trail, which discovered that the most important motive for hiking was "spending time with friends". However other studies showed different result. In the study conducted by Asan \& Emeksiz, (2016) relaxation was ranked the first in terms of importance, while learning and sociality was rank the second, while Kim et al., (2015)concluded that hiking tourists are more likely to enjoy natural environment and escape from daily life and to pursue intimacy. In their research, Kim et al., (2015) describe pursuing intimacy as "increase intimacy with family and friends" and "have conversation with family and friends while walking", which can be categorized as socializing. 


\section{Limitations of the Study}

Although this research supports another study conducted to investigate motivation of participating in hiking, there are some limitations that should be underlined. First, it doesn't distinguish participant based on segmentation (demography or psychography) whereas each segmentation bears different characteristics. In addition, this study tested for motivation constructs that is already built by another research. Therefore, it doesn't explore other types of motivations that may be prevalent among the participants. Lastly, the oudoor activity focused on this study is hiking; it didn't investigate other types of outdoor activity such as walking, rafting, or fishing.

\section{Conclusion}

As pointed out by the result, the dimensions that forms motivation for hiking in this study was respectively learning and socializing, independent and personal, achievement and relaxation. In other words, participant spend their time between one to three days on the hiking area with the main purpose to learn more about nature and their surrounding and at the same time spending quality time with their friends and family. Viewing from attraction marketing, this is a hint for managers to provide more facilities that enable the hikers to satisfy their desire to learn and to make special bond with their friends and families. For Papandayan and Ciremai Mountain managers, we suggest to provide information board regarding with hiking track, hiking safety measurement and additional information regarding with trails in several points along the track. We also suggest to provide sufficient number of posts that can be used by the hikers to rest.

This research adds to the existing literature about hiking motivation especially in Indonesia where there is growing interest in adventure tourism. Compared with other similar studies, this research proven that hiking is driven by various motivations. This research also gives insight to hiking site managers for further development.

\section{References}

Asan, K., \& Emeksiz, M. (2016). Outdoor recreation participants ' motivations, experiences and vacation activity preferences. Journal of Vacation Marketing 1-13. https://doi.org/10.1177/1356766716676300

Buckley, R. (2010). Adventure Tourism Management 1st Edition. Butterworth-Heinemann.

Chang, H. M., Hung, J. M., \& Wang, H. Y. (2010). The Study of Participation Motivation, Enduring Involvement and Happiness of Mountain Hikers.

Cordelll, H. K., Mcdonald, B. L., Teasley, R. J., Bergstrom, J. C., Leeworthy, V. R., Chavez, D. J., Brig, S. (1999). Outdoor recreation participation trends. In Outdoor recreation in American life: $a$ national assessment of demand and supply trends (pp. 219-321).

Gibson, H. J. (1998). Sport Tourism: A Critical Analysis of Research. Sport Management Review, 1(1), 45-76. https://doi.org/10.1016/S1441-3523(98)70099-3

Gozalova, M., Shchikanov, A., Vernigor, A., \& Bagdasarian, V. (2014). Sport Tourism. Sport Tourism, 21, 92-96. https://doi.org/10.2478/pjst-2014-0009

Grabowska, J. M. (2016). Sports Tourism : Terminological Discussion. Tourism, 26.

Kim, H., Lee, S., Uysal, M., Kim, J., Ahn, K., Kim, H., ... Kim, J. (2015). Nature-Based Tourism : Motivation and Subjective Well-Being. Journal of Travel \& Tourism Marketing. 
https://doi.org/10.1080/10548408.2014.997958

Manfredo, M. J., Driver, B. L., \& Tarrant, M. A. (1996). Measuring Leisure Motivation: A Meta-Analysis of the Recreation Experience Preference Scales. Journal of Leisure Research, 28(3), 188-213. https://doi.org/10.1080/00222216.1996.11949770

Mehmetoglu, M., \& Normann, $\varnothing$. (2013). The link between travel motives and activities in nature?]based tourism. Tourism Review, 68(2), 3-13. https://doi.org/10.1108/TR-02-2013-0004

Nordbø, I., \& Prebensen, K., N. (2016). Hiking as Mental and Physical Experience. Advances in Hospitality and Leisure, Volume 11, 169-186.

Shanks, R. (2018). Adventure Travel Trends Snapshot.

Spector, J. M. (2015). The SAGE Encyclopedia of Educational Technology. SAGE Publications, Inc.

Standeven, J. \& Knop, P. (1999). Sport tourism. Human Kinetics, Champaign, III.

Svarstad, H. (2017). Why Hiking ? Rationality and Reflexivity Within Three Categories of Meaning Construction, 2216. https://doi.org/10.1080/00222216.2010.11950196 